DOI: doi.org/10.21009/IJLECR.052.19

Received: 5 June 2019

Revised: 10 June 2019

Accepted: 14 August 2019

Published: 31 December 2019

\title{
DIRECTIVE SPEECH ACTS IN THE L'ENFANT FILM BY JEAN PIERRE AND LUC DARDENNE
}

\author{
Ari Puji Astrianingsih ${ }^{1, a)}$, Ratna $^{1, \mathrm{~b})}$ \\ French Education Study Programme, State University of Jakarta ${ }^{1)}$ \\ Pujiari07@gmail.com ${ }^{\text {a) }}$,ratna@unj.ac.id ${ }^{\text {b) }}$
}

\begin{abstract}
This research aims to descibe the types of directive speech acts contained in L'enfant, a film by Jean Pierre and Luc Dardenne. The approach used is qualitative approach with analysis content method, and the data is all utterances which indicate directive speech acts in the film.

The theory used in this research is the types of directive speech acts according to Searle, such as demander, ordonner, commander, requête, mendier, prier, supplier, implorer, permettre, inviter and conseiller. Data analysis techniques refer to technique from Milles and Huberman namely data reduction, data presentation and conclusion.

The results of this research that there are 135 directive speech acts found in the L'enfant film by Jean Pierre and Luc Dardenne. Among those 135 directive speech acts, there are 10 types of directive speech acts such as demander, ordonner, commander, requete, mendier, supplier, implorer, permettre, inviter and conseiller which is dominated by 57 utterances of demander type, and the least is the implorer type with only 1 utterance.
\end{abstract}

Keywords: Film, Directive Speech Acts, Speech Acts

Language is a system of sound tags that is agreed to be used by community to communicate, and identify themselves. In other words, language is a tool of function that is issued through the means of speaking and every utterance issued has a meaning. When we speak, we will produce utterances both in oral and written form that are easily understood by the speech partners. Thus, in communicating what should be prioritized is how the messages, opinions, ideas conveyed can be received clearly by the speech partner. In communication, there is one pragmatic study called speech acts, namely the utterance of sentences that have a purpose. Delbecque (2006, p.193) argues that speech acts are act to realize every goal of a communication, whether to inform, persuade, encourage, pray for, or order the speech partners to do something. Then, Yule (2010, p.133) also has the same perception about speech act, namely that speech act is an action produced by a speaker through an utterance.

There are two meanings, namely locution meaning which has meaning based on grammatical and lexical rules only. Then the meaning of illocution is the action taken by the speech partner over what they hear. Searle (1979) divides illocutionary speech acts based on their objectives into assertive, directive, commissive, expressive, and declarative. Then it is also known that the act of speech acts as an act of influencing the interlocutor intentionally or unintentionally spoken by the speaker so that the speech partner does something about the utterance. 
The directive speech act or also known as imperative act, and it is one of the speech acts that is most often encountered in daily life. The directive speech acts have the intention to make the speech partner do what the speaker says. Delbecque (2006, p.195) argues that "par un acte directive l'on donne un ordre ou on prie quelqu'un de faire quelque chose". Based on this statement, it is clearly said that in the directive speech act there is an order from the speaker that must be carried out by the speech partner. Furthermore, Dardier (2004, p.54) argues that " "par un acte directif, l'etat prycologique exprimé est le désir ( ou le souhait, la volonté).. The statement explains that in psychological directive actions the speaker expresses his desires.

Directive speech acts are not only expressed using imperative sentences but can also be spoken indirectly in question or declarative sentences. As an example in the sentence "il fait chaud" the sentence not only has the aim to inform the speech partner that at that time the air was hot but also has the intention of commanding the speech partner to get out of the room immediately or asking the speech partner to open the window. Therefore, an understanding of directive speech acts is very important to avoid misunderstanding in communication and be intertwined in two directions properly. In this research the theory of the types of directive speech acts according to Searle (1979) is divided into 11 types namely demander, ordonner, commander, requête, mendier, prier, supplier, implorer, inviter, permettre, conseiller. The directive speech acts "demander" mean asking for information in the form of a question sentence. The directive speech acts "ordonner" are governing someone with or not using authority and also express an absolute desire. The directive speech acts "commander" is order someone to do something because the speaker has a higher power than the speech partner. The directive speech act "requete" expresses the desire of the speaker but the speech partner is not forced to fulfill that desire, the directive speech act is the speaker asking very politely for food or money, The directive speech act "prier" namely the speaker asking God for things that have not been obtained. The directive speech act "supplier" asks very politely and submissively, then the directive speech act " implorer", has the meaning of solemnly asking in a polite, urgent, and repeated manner. The directive speech act "inviter" is inviting the speech partner to go somewhere. The directive speech act "permettre", the utterance said by the speaker, makes the speech partner free to act,and the last is the directive speech act "conseiller", is the speech means that it is good if it is done by the speech partner.

Speech act is one of the pragmatic studies, therefore context is needed to study the meaning of a speech. Leech (1983, p. 13) says the context as background knowledge is shared and helps the speech partner interpret the meaning of the speaker in a particular utterance. In other words, the intention of the speaker can be easily understood by looking at the context, namely the pentur and the speech partner itself have the same knowledge in communication. The directive speech acts can also be found in the film. In the film, the audience can not only hear what is said, but also see how the expression of the speaker in speaking. With visual media the audience can also clearly understand the context behind the speech. This is what makes the film as the right object to this recherche. The film examined in this recherche is the film L'enfant. The Belgian film, directed by Jean-Pierre and Luc Dardenne, and starring Jeremie Renier and Deborah Francois, found the use of directive speech acts from various scenes. This is the problem in this study, namely what kind of directive speech acts are contained in each of the utterances in the film. In connection with this problem, the purpose of this study is to describe the types of directive speech acts contained in the film L'enfant by Jean Pierre and Luc Dardenne.

After achieving the research objectives, this research has theoretical benefits to add insight into the knowledge of researchers and language observers (students) related to pragmatic studies, especially in directive speech acts that are not studied in depth at Strata-1. Besides this research can be a reference or reference for the next researcher to study pragmatics, especially in speech act studies. Besides that, practically, this research can be used as initial learning material to understand 
pragmatics if they are going to continue their education in pragmatics. Then this research can increase the knowledge of readers and researchers related to the type of directive speech acts, so that it can help to easily understand the intentions of speech partners in communicating

The research focusing on speech acts was carried out by Jansen Andreanus, a student of Sam Ratulangi University who discussed Expressive Examination in Erin Gruwell's Freedom Writer Film. This study aims to determine the types of expressive word acts contained in the film Freedom Writer by Erin Gruwell. From this study found 51 expressive utterances and there are 6 types of actions expressive speech that expressed apology, said praise, thanked, congratulated, and expressed condolences. Furthermore, research on directive speech acts has also been conducted by Sumiatun with the title Teacher and Student Directive Speech Acts in Learning in Class III of Tipo Elementary School. This research shows that the form of directive action used is the form of questions that are useful for commanding or asking.

Referring to the two recherches, there is a common focus of research, namely speech acts. The relevance of the research conducted by Sumiatun is to use the same research focus, namely the directive speech act. The research conducted by Jansen Andreanus have similarities both in the source of the data used, namely the film or the focus of the problem in the form of speech acts. From this study, there are also things that distinguish the Sumiatun Research, using data sources in the form of conversations in the classroom, while in this study using film data sources. Then the difference with the research conducted by Andreanus Jansen focuses on expressive speech acts, while in this study focused on directive speech acts.

\section{METHOD}

This 99research is a descriptive research with content analysis method because it examines issues that require in-depth research. This research uses a qualitative approach because the results can be in the form of a description of sentences instead of numbers. The research instrument was the researcher himself using data analysis tables.

The procedure in this research consisted of 3 stages (Manzilati 2017: 61) namely, 1) data collection, 2) centralization of data, 3) data analysis. At the data collection stage, researchers found the data sources in the form of primary and secondary data sources. The primary data source in this research is the film l'enfant by Jean Pierre and Luc Dardenne, while secondary data sources in the form of books and journals that support this research. Furthermore, researchers conducted data collection activities by watching the film and looking for utterances in the film which contained receptive utterances. In the second stage is the process of determining the data that is the focus of researchers, then understanding and classifying the data into an analysis table. After the data is determined, the researcher then understands the data by analyzing each sentence or piece of dialogue based on the context contained in the film's scenario. Then the researcher classifies the data that has been collected into an analysis table that contains speech, speaker, speech partner, types, namely demander, ordonner, commander, requête, mendier, supplier, prier, implorer, inviter, permettre and conseiller and information in the form of context. The last step is the process of analyzing data, by interpreting the data based on the context in terms of the types of directive speech acts that appear in Jean Pierre and Luc Dardenne's film L'enfant

\section{RESULTS AND DISCUSSION}

Based on the analysis results, there are 135 directive utterances from 10 types of directive speech acts, there are 1) demander of 56 utterances, 2) Ordonner 27 utterances 3) requete 21 utterances, 4) commander 11 utterances), 5) permettre 5 utterances, 6) conseiller 5 utterances, 7) suppliers 3 utterances, 8) inviter 3 utterances, 9) mendier 2 utterances and 10) implant 1 utterances, while prier no data is found in the film. 
1. The directive speech act "demander" is a type of directive speech act whose purpose is to obtain information from the speech partner and the utterance that is offered in the form of a question sentence. The following are examples of speech acts of the demander directive:

Sonia: Vous faites quoi chez moi?

Apartment tenant: Bruno m'a loué

The conversation took place in Sonia's apartment when she had just returned from the hospital and wanted to meet with Bruno. The phrase described Sonia's confusion when she saw someone else in her apartment. The utterance "Vous faites quoi chez moi?" which means "what are you doing in my house?" is a directive utterance with the type of "demander" because contextually the utterance has the aim to find out what that person is doing in her apartment. In addition, the utterance is in the form of sentence questions that are marked by high intonation at the end of the sentence.

2. The directive speech acts "ordonner" is the types of directive speech acts that have the aim of tell someone to do something whether the speech partner has a higher degree or not. This directive speech act expresses a desire but is brought up by not giving the speech partner the possibility to reject it so that it is coercive. For exemple :

-Bruno! Ouvre!

The utterance occurred when Sonia had just returned from the hospital after giving birth. When she ar'rived at her apartment, she got her apartment door locked. She knocked loudly on the door while saying the phrase "Bruno! Ouvre! "Which means" Bruno! Open!" to ask Bruno to immediately open the door.

Based on this utterance, contextually it can be concluded that the utterance is the directive speech acts "ordonner" because the purpose of the speaker is to govern the speech partner to open the door. The speaker also blurted it out in a high tone which gave the impression of forcing the speech partner. In addition speakers speak the sentence using imperative sentences that are marked with the verb "ouvrir" which is conjugated into the form of a second person singular.

3. The directive speech act "requête "is a type of directive speech act that expresses the wishes of the speaker so the speech partner does something, but the speaker does not expect compliance. The following are examples of speech acts directive requête:

Bruno's friend: Et ma part?

Bruno: Tiens. Quatre euros.

The conversation took place between Bruno and his friend in their hiding place. At that time they had just distributed their stolen goods and one of Bruno's friends asked to have the stolen CD. Seeing Bruno give the $\mathrm{CD}$, another friend asked for his part by saying "et ma part?" which means "and my part?"

The sentenceis a question which is marked by high intonation at the end of the sentence. But contextually, the sentence is a directive utterance of requête because the purpose of the speaker is not information about the part, but asks to be given a part. In addition, the reaction of the speech partner who gave his part by saying "tiens, quatre euros" which means "this, 4 euros"

4. Commander is a type of directive speech act that has the aim to command the speech partner and the speaker has a higher degree of power to govern the speech partner so that the speech partner has no reason to refuse. For exemple :

-Relève-le

The sentence was made by a leader who interceded between Bruno and his family who adopted his children to his subordinates. At that time Bruno was asked to come to the old house where he had taken his son back but he did not come. When he was going to buy food at a stall, suddenly the person approached him along with his subordinates and immediately took the money while beating him until he fell. He also told his subordinates to say "Relève-le" which means "wake 
him up again" to wake up to make an agreement so that he returns all the losses that person got from canceling the sale of his child.

Based on the context, it can be concluded that the speech is a directive utterance with the type of commander because it has the aim to order his subordinates to wake Bruno. In addition, as a leader, he has full power to govern his subordinates and his subordinates also respond to wake Bruno directly without rejection.

5. Permettre is a type of directive speech act in which the speaker utters a speech that does not limit the speech partner. In other words, the speech of the speaker makes the speech partner free to act by assuming that previously there was a request to do something. For exemple :

Bruno: 450.

Bruno's friend: D'accord avec le chapeau

Bruno: OK.

The conversation took place between Bruno and his friend at night in a kiosk describing a bargaining transaction. At that time Bruno wanted to sell the stolen camera but they did not get the right price. Then his friend was attracted to a hat located on the table that turned out to be Bruno's milk. Therefore when Bruno offered to sell it for 450 euros and his friend agreed, she asked Bruno to sell it together with his hat.

The utterance "ok" spoken by Bruno is a directive utterance with the type of permettre or granting permission because there is an agreement from Bruno at the request of his friend to sell his camera and hat at the same time with the price of 450 euros.

6. The directive speech act Conseiller is a type of directive speech acts where the speaker utters utterances which are deemed a good thing if done by the speech partner and is in the interests of the speech partner. For exemple:

-Non, mets ta mains Ià. En dessous de sa tête.

The statement was said by Sonia to Bruno on the side of the road. At that time Sonia was showing their child. He asked Bruno to carry their child but Bruno refused because he was afraid he would wake him up. Hearing this reason, Sonia suggested a way to hold their child so as not to wake up by saying "Non, mets ta mains là. En dessous de sa tête. " which means "no, put your hand there, under his head"

Based on the utterance, the sentence form is an imperative sentence form that functions to order the speech partner that is from the verb "mettre" conjugated into the form of the second person singular. But contextually the speech is included in the type of speech act of the conseiller directive or suggests because the speaker gives suggestions that make the speech partner feel unafraid to hold their child by telling them the correct way to carry their child.

7. Supplier is directive speech acts to ask politely and subject by saying sentences that can manipulate the speech partner to be able to give what is asked and make the speech partner feel sad and compassionate. For exemple:

Pardonne-moi, Sonia

The phrase came from a conversation between Bruno and Sonia at night in Sonia's apartment. Sonia didn't answer when he knocked on the door of her apartment, therefore she decided to wait for Sonia outside the apartment. Seeing Sonia coming, he immediately approached Sonia then knelt and held Sonia's leg while saying "Pardonne-moi, Sonia" which means "forgive me Sonia"

Based on the phrase, contextually the phrase is a directive speech act with the type of supplier because it has the objective to apologize to the speech partner. In addition, the speaker also act emotionally by kneeling and holding the feet of the speech partner.

8. Inviter is directive speech act which purpose is to ask the speech partner to go to a place or attend something and that is something that is good for the speech partner. For exemple : 
-Ils sont partis. Allez, Viens. On sort.

The utterance came from a conversation between Bruno and Steve in the river while they were hiding from the pursuit of the police and the mother who was his target. After hiding for a long time in the river, finally Bruno saw that the situation was safe because the police and the mother were not seen again. Therefore, he invited Steve to get out of the river while saying "Ils sont partis. Allez, Viens. On sort. " which means "they've left, come here, we're out"

Based on the utterance, the sentence is contextually a directive speech with an inviter type because it has the goal to get the speech partner out of their hiding place. In addition there are the words allez and viens which means to invite speech partners.

9. Mendier is a directive speech acts that have the meaning of asking but humbly and also expressing a very strong desire from a speaker who usually takes money or food from the speech partner but in general the speaker does not know the speech partner. For exemple :

Excusez-moi Vous auriez pas une petite pièce?

The utterance was spoken by Bruno to pedestrians. At that time Bruno was asked by Sonia to go to take Jimmy for a walk. But along the way, he said "Vous auriez pas une petite pièce?" which means "you have money?" to people he met on the street to ask for money from them.

The utterance is directive speech with a type of mendier although it is spoken in the form of sentence questions but contextually it has the purpose of asking money to the speech partner. In addition there is a word that means money in the sentence that is in the word "pièce" which means coin.

10. Implorer is a directive speech acts to expresses a strong and urgent desire in a polite and continuous manner to persuade the speech partner to do what he says. For exemple:

Je voudrais juste un peu d'argent. J'ai faim. Je te le jure, j'ai faim.

The utterance took place at night in Sonia's apartment. At that moment Bruno came to see her to apologize for his mistake. But Sonia chose not to talk to Bruno, even though Bruno had begged on her knees. Bruno followed Sonia to the front door of his apartment, he persuaded her not to leave him by saying that he loved her but, Sonia no longer believed, she immediately closed the door and then with a tone of despair, he said "Je voudrais juste un peu d'argent. J'ai faim. Je te le jure, j'ai faim "which means" I only want a little money. I am hungry. I swear, I'm hungry "

The utterance is contextual has a purpose o to request the speech partner to give money. The utterance is delivered with polite sentences, namely the use of the verb "vouloir" which is conjugated into the conditionnel. Then the utterance illustrates the strong desire of the speaker, its seriousness and that it is very important and urge9nt, which is seen in the next sentence "J'ai faim. Je te le jure, j'ai faim ". Therefore it can be concluded that the utterances are directive utterances.

\section{CONCLUSION}

Based on the results of the research that has been presented, it can be concluded that the type of directive speech acts in the film L'enfant by Jean Pierre and Luc Dardenne are dominated by the types of directive speech acts "demander" with as many as 57 utterances and the least utterance is the directive speech acts "implorer" with 1 utterance. Then in this study found no type of prier directive speech acts. In the directive speech acts "requete", speakers often use question sentences to ask for something. The types of directive speech acts ordonner and commander have in common to govern someone but in the type of "commander", the speaker must have more authority than the speech partner. Then in the type of speech acts prier and implorer, both can be addressed to God but in the type of directive speech acts "implorer" thrown because the speaker is in an emergency situation so he really needs help. 


\section{REFERENCES}

Andreanus, Jansen.2015. Tindak Ujar Ekspresif Dalam Film Freedom Writer Karya Erin Gruwell Suatu Kajian Pragmatik. Manado: Universitas Sam Ratulangi Fakultas Ilmu Budaya

Delbecque, N. (2006). Linguistique Cognitive: Comprendre Comment Function Le Langage.

Bruxelles: de Boeck \& Larcier s.a.

Dardier, Virginie. (2004). pragmatique et Pathologies. Comment étudier les troubles de l'usage du langage. Paris: Breal.

Leech, Geoffrey N. (1983). Principles of Pragmatics . London: Longman.

Milles, M. dan Huberman ,M.A. (1992). Analisis Data Kualitatif : Buku Sumber Tentang MetodeMetode Baru . Jakarta: Universitas Indonesia.

Searle, John. (1979). Expression and Meaning Studies in The Theory of Speech Acts. Cambridge: Cambridge University Press. 